that aspirin has a profound effect on platelet behaviourthe effects of two tablets can be detected for several days 4 -yet although aspirin has been shown to prolong the bleeding time its use has never been found to be a major surgical hazard. If volatile anaesthetics carry a theoretical risk of bleeding during surgery, they presumably also provide a theoretical benefit to the patient in preventing postoperative venous thrombosis.

1 Hampton, J. R., American fournal of Cardiology, 1971, 27, 659. Ueda, I., Anesthesiology, 1971, 34, 405.

Bigg, R., Anesthesiology, 1971, 34, 405. Human Blood Coagulation and its Disorders, 3rd edn. Oxford, Blackwell Scientific Publications, 1962. O'Brien, J. R., Lancet, 1968, 1, 779 .

Weiss, H., and Aledort, L. M., Lancet, 1967, 2, 495.

\section{Fibromuscular Hyperplasia of the Internal Carotid Artery}

Completed strokes and transient ischaemic attacks frequently arise from disease of the extracranial vessels in the neck. Far the commonest cause is arteriosclerosis, producing either thrombosis of the vessel or microembolism of the intracranial arteries. But a number of other conditions may be responsible for a similar picture, particularly in younger patients.

States of hypercoagulation including polycythaemia rubra vera, pregnancy and the puerperium, and treatment with oral contraceptives may cause thrombosis without disease of the arterial wall. Among diseases of the arterial wall is syphilitic arteritis, which, though it may have been the commonest cause 150 years ago, is now rare. Direct trauma to the carotid artery in the neck may cause thrombosis, ${ }^{1-3}$ and one cause of injury to bear in mind is direct carotid arteriography.4-6 Spontaneous dissecting aneurysms of the carotid artery, ${ }^{7}$ various arteritides including Takayasu disease, diffuse arteritis, and giant cell ("temporal") arteritis, ${ }^{8} 9$ and collagen vascular diseases 1011 may all occasionally be responsible. Particularly in children, inflammation of the wall of the carotid artery from adjacent cervical adenitis may occasionally cause thrombosis. ${ }^{12} 13$ Hypoplasia of the internal carotid artery may be the anatomical substrate for a stroke, ${ }^{14}$ though it is important to recognize that the angiographic appearance of hypoplasia may frequently be seen beyond a stenosis in a vessel which is in fact of normal calibre ("the post-stenotic carotid slim sign"). ${ }^{15}$ In rare cases no cause can be found for the carotid thrombosis. ${ }^{16}$

To be added to this list is fibromuscular hyperplasia of the carotid arteries, a condition similar in nature to that causing renal artery stenosis and hypertension. The patient may present with a completed stroke due to carotid thrombosis, or with a variety of transient cerebral ischaemic symptoms, which may sometimes be related to head turning. Often a bruit can be heard over the cervical vessels. The classic arteriographic picture of this disease is of a "string of beads" of alternating constriction and dilatation of the normally smooth outline of the internal carotid artery. ${ }^{17} 18$ However, this angiographic appearance is insufficient evidence to allow a firm diagnosis of the disease to be made, for a similar picture may result from spasm of the carotid artery, particularly when related to a difficult puncture of the artery during arteriography. Surgical inspection and pathological examination of the vessel is the only absolute way of making the diagnosis.

The pathological picture ${ }^{19}$ is similar to that of the more widely studied condition in the renal arteries. There it is recognized that stenosis may result from involvement of the intima, the media, or the adventitia, or various combinations of these. ${ }^{20}{ }^{21}$ Fibrosis of any layer may cause simple stenosis rather than the striking beaded appearance of the artery, which appears to result from damage to the internal elastic lamina, allowing focal aneurysmal dilatation between fibrotic stenoses. In arteries in which the media is affected the smooth muscle of the arterial wall may be hyperplastic and disarrayed into bundles. The aetiology of this condition is unknown, though the great predominance of women in the reported series and association of the disease with pregnancy suggest that hormonal influences may play a part. The disease appears to be widespread throughout many vessels of the body, and not restricted to the vessel causing the presenting symptoms. ${ }^{17} 18$

The classic treatment of renal artery stenosis with severe hypertension is either excision of the stenosis, with endto-end anastomosis or grafting, or nephrectomy. A similar approach has been used in the carotid territory. ${ }^{19}$ However, G. C. Morris and colleagues from Houston, Texas, ${ }^{22}$ introduced a technique of dilatation of the stenosis. The follow-up of six patients extended from two months to four years, and they reported uniformly good results, with normal postoperative angiograms. A further case of this syndrome treated by dilatation has recently been described by P. A. Lamis and colleagues from Atlanta, Georgia. ${ }^{23}$ This operation appears to be relatively simple, safe, and easier than the various other approaches, and will probably come to be the procedure of choice. Since some patients have disease of several different arteries, it has been suggested that widespread arteriography of such patients is indicated.18-23 The situation is, however, similar to that experienced with arteriosclerosis. It is probably better to adopt the conservative approach and wait to see if disease in other arteries will cause symptoms.

1 Clarke, P. R. R., Dickson, J., and Smith, B. J., British fournal of Surgery, 1955, 43, 215 .

Murray, D. S., British fournal of Surgery, 1957, 44, 556.

3 Gurdjian, E. S., Hardy, W. G., Lindner, D. W., and Thomas, L. M., Fournal of Neurosurgery, 1963, 20, 418.

Abbott, K. H., Gay, J. R., and Goodall, R. J., Fournal of Neurosurgery, 1952, 9, 258.

- Baker, H. L., Proceedings of the Staff Meetings of the Mayo Clinic, 1960

- Lindner, D. W., Hardy, W. G., Thomas, L. M., and Gurdjian, E. S., Fournal of Neurosurgery, 1962, 19, 179

'Brice, J. G., and Crompton, M. R., British Medical Fournal, 1964, 2, 790. Shrire, V., and Asherson, R. A., Quarterly fournal of Medicine, 1964, 33, 439.

- Russell, R. W. R., Quarterly fournal of Medicine, 1959, 28, 471.

10 Dubois, E. L., Commons, R. R., Starr, P., Stein, C. S., and Morrison, R., fournal of the American Medical Association, 1952, 149, 995.

11 Lee, J. E., and Haynes, J. M., Neurology (Minneapolis), 1967, 17, 18.

12 Bickerstaff, E. R., British Medical fournal, 1964, 2, 82.

13 Davie, J. C., and Coxe, W., Archives of Neurology (Chicago), 1967, 17, 313.

16 Smith, K. R., Nelson, J. S., and Dooley, J. M., Neurology (Minneapolis), $1968,18,1149$.

16 Lippman, H. H., Sundt, T. M., and Holman, C. B., Mayo Clinic Pro-

ceedings, 1970, 45,762 .
10 Adams, J. H., and Graham, D. I., fournal of Neurology, Neurosurgery and

Psychiatry, 1967, 30, 479.
17 Palubinskas, A. J., Perloff, D., and Newton, T. H., American fournal of Roentgenology, 1966, 98, 907.

18 Wylie, E. J., Binkley, F. M., and Palubinskas, A. J., American fournal of Surgery, 1966, 112, 149.

10 Connett, M. C., and Lansche, J. M., Annals of Surgery, 1965, 162, 59.

${ }^{\circ}$ McCormack, L. J., Poutasse, E. F., Meaney, T. F., Noto, T. J., and Dustan, H. P., American Heart fournal, 1966, 72, 188.

21 Crocker, D. W., Archives of Pathology (Chicago), 1968, 85, 602.

2 Morris, G. C., Lechter, A., and De Bakey, M. E., Archives of Surgery, $1968,96,636$.

23 Lamis, P. A., Carson, W. P., Wilson, J. P., and Letton, A. H., Surgery, 